\title{
The Effect of Xylitol on Dental Caries
}

Elza I. Auerkari

\begin{abstract}
Abstrak
Efek xylitol yang menguntungkan dalam pencegahan karies gigi baik dalam jangka pendek maupun jangka panjang, terutama berhubungan dengan pengurangan perlekatan plak pada permukaan gigi. Secara invitro, xylitol memodifikasi sintesis polisakarida sukrosa di dalam Streptococcus mutans, dengan demikian akan menurunkan kemampuan streptokokus untuk melekat pada permukaan yang keras. Pada pemakaian jangka panjang akan terjadi kehilangan sensitivitas mutans streptococci terhadap xylitol, akan tetapi kemampuan streptokokus yang resisten terhadap xylitol untuk menyebabkan karies dengan adanya glukosa, masih lebih rendah dibandingkan streptokokus yang sensitif terhadap xylitol. Akibatnya, penggunaan jangka panjang akan mengubah prevalensi strain mutans streptococci menjadi strain-strain dengan kemampuan yang rendah dalam menyebabkan karies. Dapat pula dijelaskan bahwa jumlah mutans streptococci pada permukaan gigi dan di dalam plak menurun menurut besaran tertentu selama kebiasaan pengunyahan permen karet xylitol dalam jangka panjang. Hal ini terutama disebabkan oleh rendahnya perlekatan plak, dan bukan karena hambatan intrinsik dalam mutans streptococci, mengingat jumlah bakteri dalam saliva pada prinsipnya tidak terpengaruh selama penggunaan xylitol dalam jangka panjang. Walaupun demikian, tidak sebagaimana pemanis 6-karbon, xylitol tidak dimetabolisir oleh streptokokus. Telah pula dilaporkan mengenai efek positif penggunaan xylitol pada remineralisasi. Pemberian xylitol sebagai pemanis permen karet, merupakan sarana yang efektif untuk memasukan xylitol dengan jumlah yang cukup pada permukaan gigi. Dosis yang memadai dianjurkan sebesar kurang lebih 8 gram per hari.
\end{abstract}

\begin{abstract}
Both the short and long term beneficial effects of xylitol in dental caries prevention appear to be mainly related to decreased adherence of the plaque to the tooth surfaces. In vitro, xylitol modifies the synthesis of polysaccharides from sucrose in Streptococcus mutans, thereby decreasing the ability of streptococci to adhere to hard surfaces. In long term habitual use some loss of sensitivity of mutans streptococci to xylitol occurs, but the ability of "xylitol resistant" streptococci to cause caries in the presence of glucose is still lower than that of more xylitol-sensitive streptococci. As a result, the long term use will change the prevalent strains of mutans streptococci to strains with decreased ability to cause caries. In addition, the levels of mutans streptococci on tooth surfaces and the plaque are decreased by an order of magnitude over a long term course of habitual xylitol consumption as in chewing gum. This is probably mainly due to the low adherence of the plaque and not due to the intrinsic inhibition of mutans streptococci, since the bacterial counts in saliva are essentially unaffected in long term use of xylitol. However, unlike six-carbon sweeteners, xylitol is not metabolised by the streptococci. Positive effects of xylitol consumption on dental remineralisation have also been reported. Chewing gum sweetened with xylitol appears to be an effective vehicle to introduce sufficient amounts of xylitol to the tooth surfaces. The sufficient dose is suggested to be about $8 \mathrm{~g} /$ day.
\end{abstract}

Keywords : xylitol, dental caries

Infections of the teeth and oral mucosa are caused by micro-organisms in dental plaque, from which hundreds of bacterial species have been identified. Of these, particularly Streptococcus mutans, Streptococcus sobrinus and their relatives (collectively known as "mutans streptococci") and lactobacilli are associated with the development of dental caries. Since the mutans streptococci belong to the viridans group, they are also significant in causing local infections of the mouth.

Department of Oral Biology, Faculty of Dentistry University of Indonesia, Jakarta, Indonesia
In the control of dental plaque-born problems and for improvement of the oral hygiene, traditionally both mechanical cleaning and chemotherapeutic agents (e.g. chlorhexidine in mouthwash or fluorides in toothpaste) have been used. Since the 1980's, xylitol has been found to be a particularly interesting chemotherapeutic agent in caries control. ${ }^{1}$

Xylitol is a simple five-carbon non-cariogenic sugar alcohol, which is used as a sweetener to replace sucrose in the food industry, candies, chocolates, chewing gums and other products. As the taste of xylitol is not quite the same as with sucrose, it is often used in 
combination with other sweeteners such as sorbitol and mannitol. However, it is particularly the potential of the xylitol in caries prevention that has provoked much dental research into xylitol. In this respect the effects have been attributed to both microbiological and physicochemical actions of xylitol. ${ }^{1,2}$

Several methods have been used in introducing xylitol to the teeth, including toothpaste, chewing gum and mouthwash ${ }^{1-9}$ This review attempts to summarize the experience with xylitol and xylitol carriers and their effectiveness in controlling dental caries.

\section{Effects of Xylitol on Oral Micro-organisms}

In vitro, xylitol modifies the synthesis of polysaccharides from sucrose in Streptococcus mutans, thereby decreasing the ability of streptococci to adhere to hard surfaces. ${ }^{1,2,8}$ In vitro studies have also suggested that in high concentrations xylitol could cause ultrastructural changes in streptococci, ${ }^{10}$ which in turn could affect the adhesion properties. However, other studies indicate that it is the adherence of the plaque rather than the adherence of the streptococci directly that is lowered by xylitol. ${ }^{8}$ An additional important mechanism arises from the observed inability of the oral bacteria to metabolise xylitol. This contrasts with the bacterial metabolism of six-carbon simple sugars and many artificial sweeteners such as sorbitol that can be metabolised to some extent.

A continued use of xylitol initially also causes the salivary levels of mutans streptococci to decrease; this has been related to the formation of intracellular xylitol 5 -phosphate. ${ }^{1,8,11}$ However, usually within a few months more xylitol resistant $\mathrm{X}_{\mathrm{R}}$-cells will dominate, and the salivary levels of mutans streptococci will rise back to the level preceding xylitol treatment. Other oral micro-organisms such as lactobacilli or yeast are not much affected by xylitol. ${ }^{9}$ The most important long term change appears to be the lowered caries-promoting ability of the emerging prevalent xylitol resistant strains of mutans streptococci. ${ }^{12,13}$

Xylitol may exhibit also some more indirect effects: it has been reported that xylitol can inhibit enamel demineralisation in vitro. ${ }^{12}$ The effect of xylitol can be in many cases additive with the influence of e.g. fluorides or chlorhexidine against plaque, and hence it may be beneficial to combine other agents with xylitol for this purpose. In the case of chlorhexidine, the practical limitation in many applications is the fairly unpleasant bitter taste of chlorhexidine.

\section{Physico-chemical Action of Xylitol}

Practically all clinical field studies confirm that habitual xylitol consumption will permanently lower the plaque mutans streptococci counts on tooth surface, and thus also decrease significantly the incidence of caries. ${ }^{1-9}$ This also confirms the close relationship between mutans streptococci and dental caries. It is notable that the beneficial function of xylitol is realised without much effect on the levels of lactobacillus, yeast or even salivary streptococci.

In one study initially with 324 children (11 to 12 years old at the start) over a 2-3 year period, adding xylitol 7-10 g per day, consumed as chewing gum at least twice daily to supplement the basic fluoride-based caries prevention, resulted in an additional decrease of caries by $30-60 \%$, the lower rate corresponding to the lower end of xylitol consumption. In a follow-up study with 46 of these children over an additional 3 year period (Table 1), the beneficial effect of xylitol (now at least $1.2 \mathrm{~g}$ daily) was confirmed. ${ }^{1}$ In addition, even if long term habitual xylitol consumption is interrupted, significantly lower caries levels persist in children for years after discontinuation than in control groups (with fluoride treatment only).

Table 1. Mean values of clinical caries prevalence in 46 children over a 6 year period according to habitual xylitol usage as chewing gum

\begin{tabular}{|c|c|c|c|c|c|}
\hline Group & $\mathbf{N}$ & $\mathrm{D}_{1-2} \mathrm{~T}$ & $\mathrm{D}_{1-2} \mathrm{MFT}$ & $\mathrm{D}_{2} \mathrm{~T}$ & $\mathrm{D}_{2} \mathrm{MFT}$ \\
\hline $\mathrm{CC}$ & 17 & 4.7 & 10.1 & 1.1 & 7.8 \\
\hline $\mathrm{CX}$ & 5 & 2.4 & 6.6 & 0.2 & 5.0 \\
\hline $\mathrm{XC}$ & 14 & 3.6 & 6.9 & 0.6 & 4.4 \\
\hline $\mathrm{XX}$ & 10 & 1.3 & 4.3 & 0.1 & 3.1 \\
\hline \multicolumn{2}{|c|}{$\Sigma \mathrm{N}=46$} & $\begin{array}{l}\mathrm{XX} / \mathrm{CC}^{* *} \\
\mathrm{XX} / \mathrm{XC}^{*}\end{array}$ & $\begin{array}{l}\mathrm{XX} / \mathrm{CC}^{* *} \\
\mathrm{XC} / \mathrm{CC}^{* *}\end{array}$ & $\mathrm{XX} / \mathrm{CC}^{* *}$ & $\begin{array}{l}\mathrm{XX} / \mathrm{CC}^{* *} \\
\mathrm{XC} / \mathrm{CC}^{* *}\end{array}$ \\
\hline
\end{tabular}

\footnotetext{
Group XX : continuous xylitol use 1982-1988

Group CX : no xylitol use 1982-84, continuous use 1985-88

Group CC : no regular use of xylitol 1982-88

Group XC : continuous xylitol use 1982-84, no use 1985-88

Caries rating : $D_{1}$ enamel caries, $D_{2}$ dentin caries

$\mathrm{D}_{1-2} \mathrm{~T}$ sum of enamel and dentin caries teeth

$D_{2} T$ includes teeth with dentin caries only

(7; reproduced by permission of Caries Res)
}

Most field studies of the effects of xylitol on dental caries have been carried out with xylitol consumption in the form of chewing gum. ${ }^{1-8}$ Similar degree of 
protection against caries has not been shown using xylitol only through mouthwash or toothpaste. In one study with a mouthwash the apparent good results in controlling mutans streptococci were possibly mainly related to chlor-hexidine that was used together with xylitol. This study was also short term in character, and hence can provide no conclusions regarding caries protection. ${ }^{9}$ In another study on the effect of added xylitol in a toothpaste, the results from a 3-year period involving 284 children were not particularly conclusive, possibly because of relatively small concentration of xylitol in the toothpaste. ${ }^{6}$ There may have been some beneficial effect of xylitol for children with no detectable approximal caries at baseline, but in comparison with the clear benefits of xylitol in chewing gum, the improvement was fairly marginal. ${ }^{6}$ For designing toothpaste composition xylitol could be used with lowered fluorine concentration, both for caries inhibition and for avoiding dental fluorosis in children undergoing enamel mineralization. More convincing positive effect of xylitol has been obtained with chewing gum sweetened with xylitol (Fig 1). Two studies in particular have shown promising effect of xylitol in caries prevention. ${ }^{13-15}$

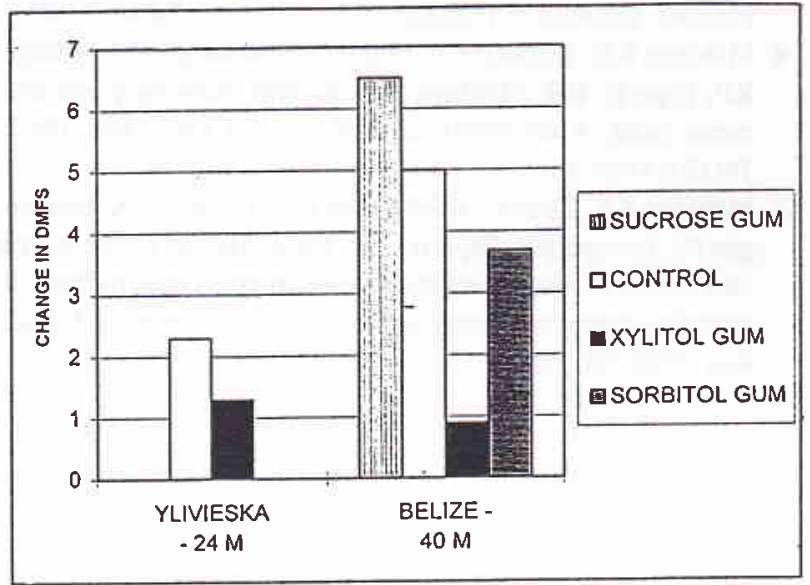

Figure 1. Increase in DMFS scores for caries in two studies on school children: (left) a 24 month study in Ylivieska, Finland $(N=324)$ with initial age of $11-12$ years and initial mean DMFS score of 4.5-5.3 (13); and (right) a 40 month study in Belize, Central America $(N=1135)$ with an initial mean age of 10.2 years and initial mean DMFS score of 4.0-6.8 (14,15). In both studies xylitol was given 3 gums/day (65\% xylitol), and in the latter study sucrose gums and sorbitol gums 5 gums/day. The observed reduction in caries onset rates associated with xylitol gums was significant in comparison with control $(p<0.001)$, sucrose gums $(p<0.0001)$ and sorbitol gums $(p<0.001)$. Note also that use of sorbitol gums significantly (though less than xylitol gums) reduced caries onset rates in comparison with control $(p<0.01)$ and sucrose gums $(p<0.001)$.
That chewing gum as xylitol carrier has proven particularly successful in prevention of dental caries could be partly explained by the prolonged smearing action of gum chewing that provides probably a longer and more thorough contact between xylitol and the tooth surfaces in comparison with mouthwash or traditional mechanical cleaning. However, the smearing action alone does not explain the effect of xylitol chewing gum, as can be seen by comparing the results between chewing gum effects with xylitol or sorbitol, as well as with different concentrations of xylitol. ${ }^{14,15}$ Clearly smaller positive effect has been observed with chewing gum sweetened with sorbitol, probably at least partly because sorbitol can be to some extent metabolised by oral streptococci. The positive effect of xylitol is also significantly decreased by reducing the concentration of xylitol in the chewing gum. ${ }^{14}$ An important aspect is the relatively high concentration of xylitol in chewing gums $(20-65 \%)$, which is much higher than the usual less than $10 \%$ levels of sweeteners in toothpastes. This is suggested to translate to a sufficient xylitol dose of about $8 \mathrm{~g}$ per day. ${ }^{14}$

\section{Summary}

The beneficial effects of xylitol appear to be mainly related to decreased adherence of the plaque to the tooth surfaces. In vitro, xylitol modifies the synthesis of polysaccharides from sucrose in Streptococcus mutans, thereby decreasing the ability of streptococci to adhere to hard surfaces. In long term habitual use some loss of sensitivity of mutans streptococci to xylitol occurs, but the ability of "xylitol-resistant" streptococci to cause caries in presence of glucose is permanently lowered by using xylitol. In addition, the levels of streptococci on tooth surfaces are decreased by an order of magnitude over a long term course of habitual xylitol consumption as chewing gum. This and the resulting benefit in caries prevention are mainly due to low adherence of the plaque and not due to inhibition of streptococci, since the bacterial counts in saliva are essentially unaffected in long term use of xylitol. However, unlike six-carbon sweeteners xylitol is not metabolised by the streptococci, and in long term use the resulting prevalent strains of mutans streptococci are changed to strains that have lowered ability to cause caries. Positive effects of xylitol consumption on dental remineralisation have also been reported.

An effective vehicle of introducing xylitol to the tooth surfaces appears to be chewing gum sweetened with xylitol. The required dose has been estimated as about $8 \mathrm{~g} /$ day. Other vehicles, such as mouthwash or tooth- 
paste have not been as successful, possibly due to small doses and the lacking additive effect of extended smearing action of the chewing gums. The smearing action alone does not explain the effect of xylitol chewing gum, as much smaller positive effect can be seen with chewing gum sweetened with sorbitol, and the positive effect is also reduced by reducing the concentration of xylitol in the chewing gum.

\section{Acknowledgement}

The author wishes to gratefully acknowledge the advice and guidance to sources by Prof P. Alanen and Dr E. Soderling of the Institute of Dentistry, University of Turku, Finland.

\section{REFERENCES}

1. Isokangas P, Alanen P, Tiekso J, Mäkinen KK. Xylitol chewing gum in caries prevention: a field study in children. J Am Dent Assoc 1988; 117: 315-20.

2. Mäkinen KK. Latest dental studies on xylitol and mechanism of action of xylitol in caries limitation. In: Grenby T, eds. Progress in Sweeteners. London: Elsevier 1989: 331-62.

3. Trahan L, Söderling E, Drean M, Chevrier MC, Isokangas $P$. Effect of xylitol consumption on the plaque-saliva distribution of mutans streptococci and the occurrence and long-term survival of xylitol-resistant strains. J Dent Res 1992; 71(11): 1785-91.

4. Nuuja TT, Murtoma HT, Meurman JH, Pesonen TJ. The effect of an experimental chewable antiplaque preparation containing chlorhexidine on plaque and gingival index scores. J Dent Res 1992; 71(5): 1156-8.

5. Olsson H, Spak CJ, Axell T. The effect of a chewing gum on salivary secretion, oral mucosal friction, and the feeling of dry mouth in xerotomic patients. Acta Odontol Scand 1991; 49: 273-9.
6. Petersson LG, Birkhed D, Gleerup A, Johansson M, Jönsson G. Caries preventive effect of dentifrices containing various types and concentrations of fluorides and sugar alcohols. Caries Res 1991; 25: 74-9.

7. Isokangas P, Tenovuo J, Söderling E, Männistö H, Mäkinen KK. Dental caries and mutans streptococci in the proximal areas of molars affected by the habitual use of xylitol chewing gum. Caries Res 1991; 25: 444-8.

8. Söderling E, Isokangas $P$, Tenovuo J, Mustakallio S, Mäkinen KK. Long-term xylitol consumption and mutans streptococci in plaque and saliva. Caries Res 1991; 25: 153-7.

9. Nuuja T, Meurman JH. Effect of experimental antiplaque preparation on salivary microbial counts in military academy cadets refraining from mechanical cleaning of the teeth. Military Medicine; 157(3): 121-4.

10. Tuompo H, Meurman JH, Lounatmaa K. Effect of xylitol and other carbon sources on the cell wall of Streptococcus mutans. Scand J Dent Res 1983; 91: 17-25.

11. Assev S, Vegarud G, Rolla G. Growth inhibition of Streptococcus mutans strain OZM 176 by xylitol. Acta Pathol Microbiol Immunol Scand 1980; B 88: 61-3.

12. Arends J, Christoffersen J, Schuthof J, Smits MT. Influence of xylitol on demineralization of enamel. Caries Res 1984; 18: 296-301

13. Isokangas PJ. Xylitol chewing gum in caries prevention. A longitudinal study on Finnish school children. [dissertation]. Finland: Institute of Dentistry, University of Turku. 1987.

14. Mäkinen KK, Bennett CA, Hujoel PP, Isokangas PJ, Isotupa KP, Pape Jr. HR, Mäkinen P-L. Xylitol chewing gums and caries rates: a 40-month cohort study. J Dent Res 1995; 74(12): 1904-13.

15. Mäkinen KK, Chen C-Y, Mäkinen P-L, Bennett CA, Isokangas PJ, Isotupa KP, Pape Jr. HR. Properties of whole saliva and dental plaque in relation to 40 -month consumption of chewing gums containing xylitol, sorbitol or sucrose. Caries Res 1996; 30: 180-8. 